\title{
Reflections on the History of the Canadian Association for Child Neurology
}

\author{
Henry G. Dunn and John A.R. Tibbles
}

\begin{abstract}
The Canadian Association for Child Neurology (CACN) was founded in June 1971 to combine neurologists interested in children and paediatricians interested in the nervous system into an organization which would promote the development of this subspecialty. Initially, the members of the Association mostly wished to have a training programme under the combined supervision of University Departments of Paediatrics and Neurology. However, under the influence of the Royal College of Physicians \& Surgeons of Canada, and its Committee on Neurology, the training of child neurologists was organized in a manner analogous to that of neurologists for adults, though with an initial one or two years of paediatrics instead of medicine. By 1975, four years within a recognized neurological training programme could lead to the Certification Examination in Neurology, as modified for paediatric neurology. In 1981, the CACN also joined the Canadian Congress of Neurological Sciences. It has played an increasing part in child care and also in academic studies. However, evidence will be presented to show that the present number of paediatric neurologists in Canada is insufficient. The number of trainees also appears inadequate, and increased funding for training positions is needed. Close cooperation between paediatric neurologists, rehabilitation experts, developmental paediatricians and related subspecialists is required.
\end{abstract}

\begin{abstract}
RÉSUMÉ: Réflexions sur l'histoire de l'Association canadienne de neurologie pédiatrique. L'Association canadienne de neurologie pédiatrique (ACNP) a été fondée en juin 1971 pour réunir les neurologues intéressés aux enfants et les pédiatres intéressés au système nerveux dans le but de promouvoir le développement de cette sous-spécialité. Initialement, les membres de l'Association désiraient surtoụt avoir un programme de formation sous la supervision conjointe de départements universitaires de pédiatrie et de neurologie. Cependant, sous l'influence du Collège royal des médecins et chirurgiens du Canada et de son Comité de neurologie, la formation des neurologues pour enfants a été organisée de la même façon que celle des neurologues pour adultes, avec une ou deux années de pédiatrie au lieu de médecine. En 1975, quatre ans d'entraînement dans un programme reconnu de neurologie pouvaient mener aux examens de certification en neurologie, modifiés pour la neurologie pédiatrique. En 1981, l'ACNP s'est également jointe au Congrès canadien des sciences neurologiques. Elle a joué un rôle de plus en plus grand dans le soin des enfants et dans la formation académique. Cependant, nous présenterons des données démontrant que le nombre actuel de neurologues pédiatriques au Canada est insuffisant. Le nombre des étudiants en formation semble aussi inadéquat et il faut augmenter les fonds destinés à l'entraînement. De plus, une coopération étroite doit exister entre les neurologues pédiatriques, les experts en réhabilitation, les pédiatres du développement et les sous-spécialités.
\end{abstract}

Can. J. Neurol. Sci. 1998; 25: 328-335

In the 1950 s and $1960 \mathrm{~s}$, it became increasingly evident in North America that paediatrics, like internal medicine beforehand, was developing into such a complex field of knowledge that the academic centres had to foster subspecialization. In the United States paediatric neurology had been established since 1937 when Frank R. Ford first published his comprehensive textbook on Diseases of the Nervous System in Infancy, Childhood and Adolescence.

Paediatric neurologists were derived from two main sources, namely (1) neurologists who had a special interest in children, and (2) paediatricians particularly interested in the nervous system. For instance, in Boston, Drs. Philip R. Dodge and Charles F. Barlow belonged to the first group, whereas Drs. Bronson
Crothers, Randolph Byers, and Richmond Paine represented the second.

In 1958, the National Institute of Neurological Diseases and Blindness organized a committee which laid down guidelines for the training of child neurologists. ${ }^{1}$ Some modifications were suggested at a further conference under the leadership of Sidney Carter, of Columbia University, New York, in $1967 .^{2}$ In 1968 ,

From the Division of Neurology, Department of Paediatrics, University of British Columbia.

RECEIVED OCTOBER 16, 1997. ACCEPTED IN FINAL FORM MAY 25, 1998.

Reprint requests to: Henry Dunn, A326B, BC's Children's Hospital, 4480 Oak Street, Vancouver, British Columbia, Canada V6H 3V4 
the American Board of Psychiatry and Neurology then began to hold examinations for certification in neurology with special competence in child neurology.

In 1970, an estimate by the National Institutes of Health suggested that one paediatric neurologist was required for every 100,000 children under the age of 15 years. ${ }^{1,2}$ This meant that 815 practising paediatric neurologists and 510 "teacher- investigators" would be needed by $1976 .{ }^{3}$ Meanwhile in Europe, Hagberg, Ingram, and MacKeith ${ }^{4}$ expressed the view that paediatric neurologists have two main functions: diagnosis and habilitation. They promoted the concept of regional paediatric academic centres which should have a neurology unit providing clinical care, research and teaching in developmental paediatrics, in acute and chronic neurological disorders and in rehabilitation. The authors considered that there should be about one such child neurology unit per million population. It should have close access to related medical specialties and to the latest diagnostic techniques. The continuing care of children with neurological disorders requires close cooperation between paediatric and community services, and the diagnostician and the rehabilitation expert have to collaborate closely.

In Canada, the situation in 1970 was similar to that in the United States, with an increasing need for paediatric neurologists, but no official training programme. The leading neurologists for adults who were also interested in children were Preston Robb and Fred Andermann in Montreal and John Stobo Prichard in Toronto. Paediatricians interested in neurological disorders were more numerous and stretched from Halifax in the east to Vancouver in the west. In 1969, Gordon Watters (already experienced in paediatrics) had returned to Canada from Boston after taking the full American training in Neurology and had become Director of Neurology at the Montreal Children's Hospital. 5,6

\section{CACN}

One of the present authors (HGD) happened to meet two of the outstanding American child neurologists, Sidney Carter and David Clark, in 1970 and received their encouragement to organize a club for paediatric neurologists in Canada. Accordingly, the enclosed letter was dispatched on March 19, 1971 (Figure 1). At least 12 replies were received, and all supported the proposal, although some of the respondents were unable to come to the initial meeting at John Watson Hall in Kingston on June 15, 1971.

Those present were:

Dr. J.U. Crichton (Vancouver); Dr. H.G. Dunn (Vancouver); Dr. G.G. Hinton (London, Ont.); Dr. M. Lechter (Montreal); Dr. R.E. Masotti (Kingston); Dr. J.C. Steele (Toronto); Dr. J.A.R. Tibbles (Halifax).

In addition, Dr. B. Lemieux, Sherbrooke, had expressed his views in detail prior to the meeting, which he was unable to attend. Dr. R. Lafontaine, Montreal, arrived just after the meeting and agreed with the decisions (See photographs).

One of us (HGD) opened the meeting with a brief review of recent developments. He quoted the Annual Report of the Education Committee of the Canadian Paediatric Society, which had suggested in March 1971 that subspecialty training programs should be set up in conjunction with similar programs for internists, e.g., in cardiology and neurology. Accordingly, it

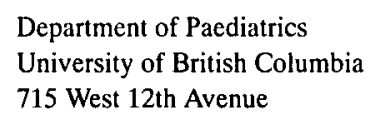

March 19, 1971

Dear

As you will agree, paediatric neurology is developing as an important subspecialty of both paediatrics and neurology in Canada as elsewhere. Increasingly I am receiving letters of enquiry from physicians who wish to be trained in this subspecialty or even in one of its branches like cerebral palsy, learning disorders, etc. As in other countries it seems essential that a training program for paediatric neurologists (or neuropaediatricians) be developed in Canada, ideally with the joint approval of the Canadian Paediatric Society and the Canadian Neurological Society. This training program might then ultimately lead to a special diploma issued by the Royal College.

It seems to me that the time has come to start discussing all this, and it would be easiest if our fraternal band of pacdiatric neurologists in Canada could get together at one of the annual meetings in 1971. Since the Canadian Neurological Society is going to meet in Newfoundland and some of our western group may not get there, 1 should suggest that we might try and meet at the annual meeting of the Canadian Paediatric Society at Kingston on June 14-16. I am therefore writing to enquire whether (a) you are in favour of such a meeting, and (b) you would be able to attend. If we cannot get any agreement on the question of a training program, we might at least start forming a club of Canadian paediatric neurologists. To facilitate your reply I am drafting the outline of an answer for you at the bottom of this page, but please feel free to add more comments on our mutual problems.

Sincerely yours,

H.G. Dunn, M.B., M.R.C.P., Professor, Department of Paediatrics

Mary'papersidunn

Figure 1: Inaugural Letter in March 1971.

seemed an appropriate time for physicians interested in child neurology to form an organization and to work towards the establishment of a specific training programme in this subspecialty. If one paediatric neurologist was required for about 100,000 children under the age of 15 years, this would mean a need for at least 60 subspecialists to work in Canada, and at that time there were only about 25 . It would, therefore, be important to establish an adequate standard of training, recognized by the Royal College. It was also evident that such a child neurology group should cooperate closely with both the Canadian Neurological and the Canadian Paediatric Societies.

It was then agreed that a new organization be established and named the Canadian Association for Child Neurology (CACN). Those interested in child neurology should be free to join this organization, but membership should initially be restricted to those residing in Canada. An annual membership fee of $\$ 2$ was 


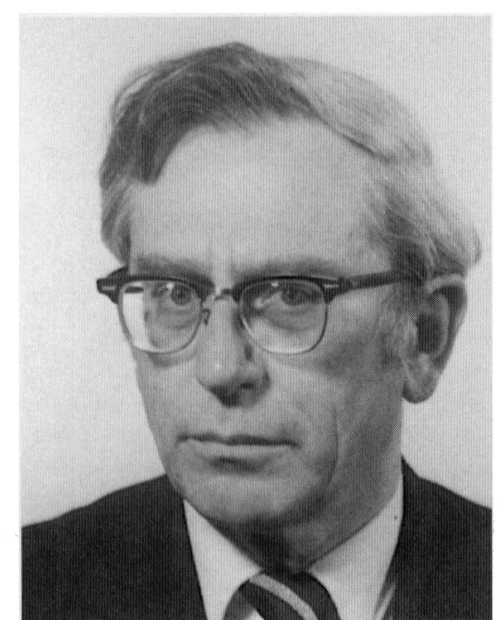

Dr. John Crichton

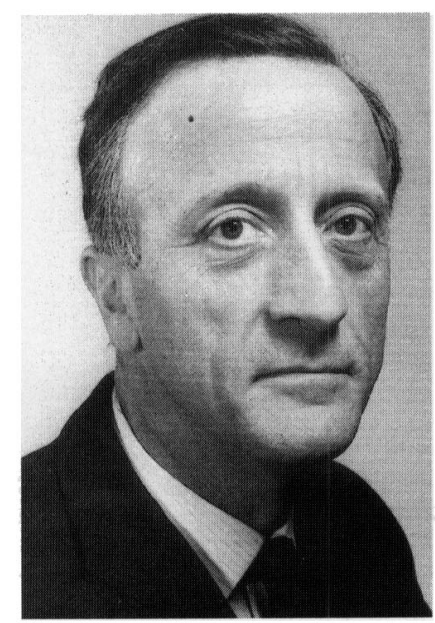

Dr. Henry Dunn

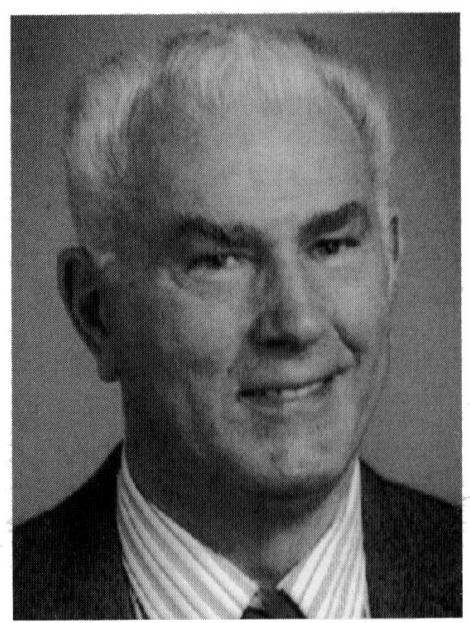

Dr. George Hinton established in order to pay for stationery, postage, and secretarial expenses. The following officers were elected pro tempore: President: Dr. H.G. Dunn, Vice-President: Dr. J.C. Steele, Secretary: Dr. J.U. Crichton (Table 1).

It was agreed that both the Canadian Neurological and the Canadian Paediatric Society should be approached to see if they could arrange at least a half-day session on child neurology at their annual meetings. However, in view of the limited number of paediatric neurologists and their restricted travel funds, it was also agreed that it might be best initially to have such half-day sessions alternately at the meetings of each society.

After this, there was considerable discussion concerning desirable training programmes for child neurologists, and this will be summarized in a separate section.

In the following year, our Association participated in the Congress of Neurological Sciences in Banff and held its annual meeting there on June 21, 1972. At that meeting, Dr. K. Meloff described current trends in the United States where the Child Neurology Society was being founded. Dr. Preston Robb moved that "there be a Canadian National Conference on anti-convulsant drugs to review the present status and future prospects, including a discussion of new drugs and of methods of estimating drug levels". This was passed, and it was decided to pursue the matter through the Council of the Canadian Neurological Society.

Elections were then held, and as Dr. Steele was leaving Canada, Drs. Dunn, Lemieux, and Tibbles were elected as officers for the following year (see Table 1).

On October 5, 1972, the Child Neurology Society in the United States had its first meeting in Ann Arbor, Michigan. More than 125 paediatric neurologists from throughout the United States and Canada participated and Dr. K. Swaiman of Minneapolis was elected President. He has recently given a description of the difficulties that had to be overcome in starting such a large national organization. ${ }^{7}$ One of us (HGD) and subsequently also Dr. Lemieux visited Dr. Swaiman in Minneapolis, and common problems and areas of cooperation between our Societies were discussed.
Table 1: Executive Officers of Canadian Association for Child Neurology.

\begin{tabular}{llll}
\hline & President & Vice-President & Secretary/Treasurer \\
\hline $1971-72$ & H.G. Dunn & J.C. Steele & $\begin{array}{l}\text { J.U. Crichton } \\
\text { (pro tempore) }\end{array}$ \\
$1972-73$ & H.G. Dunn & B. Lemieux & J.A.R. Tibbles \\
$1973-74$ & B. Lemieux & J.A.R. Tibbles & G.G. Hinton \\
$1974-75$ & J.A.R. Tibbles & G.G. Hinton & G.V. Watters \\
$1975-76$ & G.G. Hinton & G.V. Watters & R.M. Curtis \\
$1976-77$ & G.V. Watters & E.W. Gauk & R.M. Curtis \\
$1977-78$ & E.W. Gauk & P. Langevin & R.M. Curtis \\
$1978-79$ & P. Langevin & W.T. Blume & R.M. Curtis \\
$1979-81$ & W.T. Blume & R.M. Curtis & E.J. Gibson \\
$1981-82$ & R.M. Curtis & F. Andermann & E.J. Gibson \\
$1982-83$ & R.M. Curtis & F. Andermann & D.L. MacGregor \\
$1983-85$ & F. Andermann & R. Haslam & D.L. MacGregor \\
$1985-86$ & R. Haslam & K. Farrell & D.L. MacGregor \\
$1986-87$ & R. Haslam & K. Farrell & D.L. Keene \\
$1987-89$ & K. Farrell & P. Humphreys & D.L. Keene \\
$1989-91$ & P. Humphreys & S.S. Seshia & D.L. Keene \\
$1991-93$ & S.S. Seshia & D.L. Keene & W.J. Logan \\
$1993-95$ & D.L. Keene & W.J. Logan & B. Lemieux \\
$1995-97$ & W.J. Logan & B. Lemieux & A. Hill \\
\hline
\end{tabular}

\section{Development of CACN}

The next annual meeting was held in Quebec City in June 1973, in conjunction with the meeting of the Canadian Paediatric Society. At this meeting, a special half-day in paediatric neurology was first organized. It was also decided to form an Education Committee of CACN consisting of the present writers and Dr. S. Verret (of Quebec City). Further, a Constitution Committee was appointed, consisting of Drs. Lemieux, Hinton and Langevin.

It was also reported that a collaborative anti-convulsant drug trial was in progress, and Dr. F. Andermann proposed that $\mathrm{CACN}$ should act as a vehicle to register rare neurometabolic genetic diseases in Canada. 


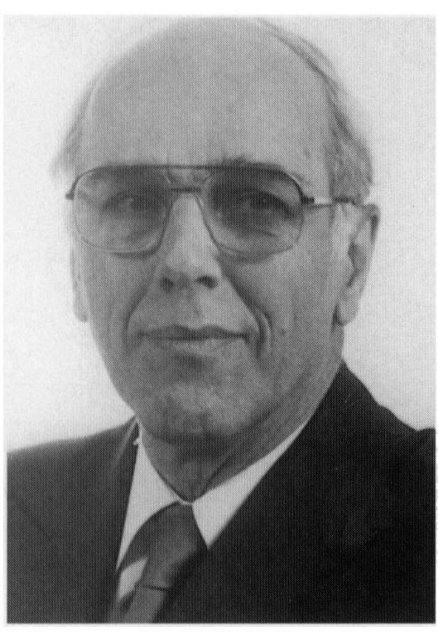

Dr. Raymond Lafontaine

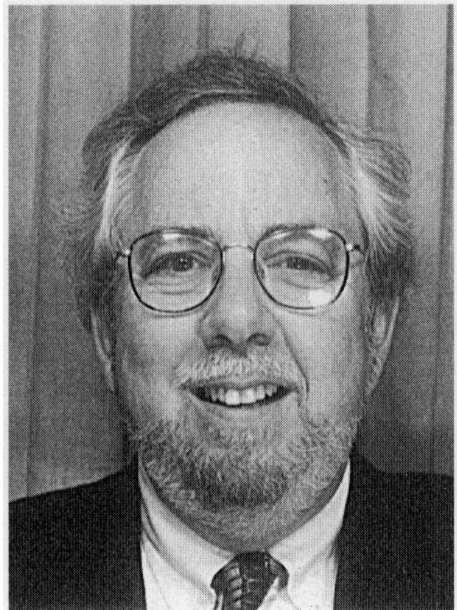

Dr. Mortimer Lechter

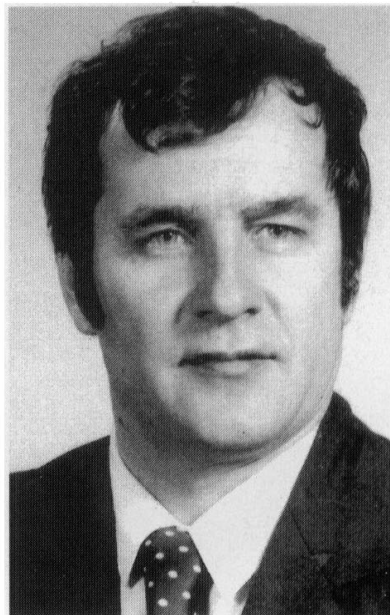

Dr. Bernard Lemieux
The next annual meeting was held in conjunction with the Canadian Congress of Neurological Sciences (CCNS) in Saskatoon in June 1974, following a half-day programme of child neurology. Dr. Stobo Prichard reported that at an international congress in Barcelona in September 1973, the International Child Neurology Association (ICNA) had been formed under his presidency, with Dr. Sabine Pelc of Belgium as Secretary. Since then, plans had been made to have the First International Congress of Child Neurology in Toronto in October 1975, and he urged members to submit papers.

By 1975 , the membership had risen to 42 , and paediatric neurologists resident in other countries were admitted. The Executive Committee of CACN decided that the Annual Meeting in 1975 might most suitably occur at the time of the International Congress in Toronto, and the Programme Committee of the Congress arranged a half-day with a scientific program for CACN. The International Congress itself was very successful and was attended by almost 750 persons from 46 nations. Most of the symposia and two special lectures were published in a book "Topics in Child Neurology", edited by Dr. Michael Blaw and others. ${ }^{8}$ At the Annual Meeting of CACN at that time, a proposed Constitution and By-laws of the Association were presented by Dr. G. Hinton.

In 1976, CACN held its Annual Meeting at the Canadian Congress of Neurological Sciences in Winnipeg. At that time, the Association honoured its two most senior members, Dr. Preston Robb and Dr. Stobo Prichard, who were presented with mounted medals commemorating their role in developing the specialty of child neurology in Canada.

The recruitment of members was also discussed, and it was suggested that trainees in pediatric neurology should be invited to become junior members, and that paediatricians interested in child neurology, e.g., developmental paediatricians, should also be invited to join.

By 1978, the difficulties of alternating between a Congress of Neurological Sciences and the Annual Meeting of the Canadian Paediatric Society were becoming evident, and the Association voted in favour of joining the Congress at all its annual meetings, and in 1981, CACN became affiliated with CCNS.
However, it still maintains a definable presence which is reflected in the Child Neurology Day at the beginning or end of the Congress. On that day, special symposia with guest speakers are usually organized, and interesting local patients may be seen and discussed. Recently it has become customary for an invited speaker of the Congress to give a special lecture on that day.

At the Annual Meeting in Ottawa in 1980, it was decided to extend the term of the President's appointment to two years and to have this person succeeded by the Vice-President. As suggested by Dr. Warren Blume, a President's prize (with plaque and cheque) was also established in 1981 for the trainee in clinical neurological science or paediatrics who presented the best paper on clinical or basic science research in paediatric neurology at the Canadian Congress.

In December 1991, the CACN was incorporated. The objects of the Corporation are: 1.) to promote the advance of knowledge of the sciences pertaining to the development of the nervous system from conception to adult life; 2.) to advance knowledge of diseases of the nervous system in children; 3 .) to stimulate prevention of neurological disease; and 4.) to foster improved treatment and care of young people with neurological handicaps.

\section{Training and Examinations}

When CACN was founded in June 1971, most Canadian specialties required four years of recognized residency training. Accordingly, the following was proposed for discussion with the Canadian Neurological and Paediatric Societies and with the Royal College of Physicians and Surgeons of Canada. After a rotating or preferably straight paediatric, internship, four years of residency training were planned, namely: One year of paediatrics, one year of neurology for adults, one year of paediatric neurology, and one year of "basic neurology" that could be divided among electroencephalography, electromyography and nerve conduction studies, neuropathology, or neurochemistry and/or neuropharmacology.

Such a four-year training was to lead to certification specifically in child neurology. Our group envisaged that this training programme would be supervised conjointly by university departments in paediatrics and neurology. The trainees would 


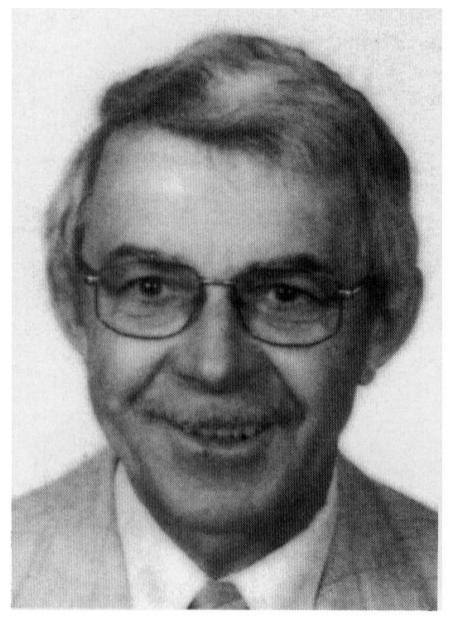

Dr. Ronald Masotti

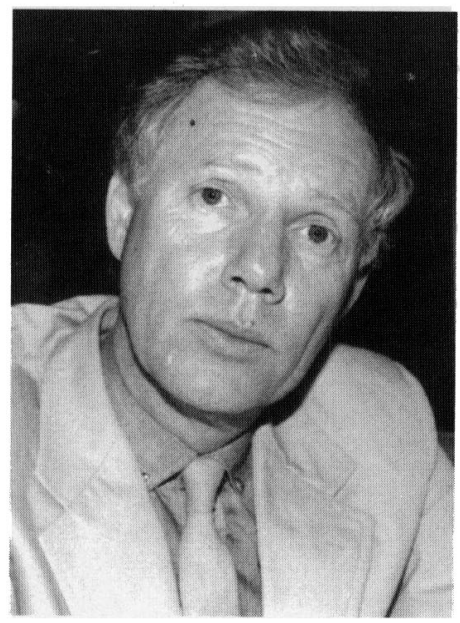

Dr. John Steele

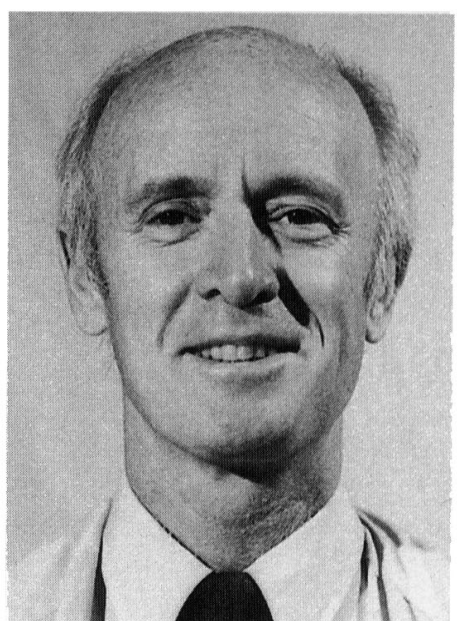

Dr. John Tibbles have an option of taking an extra year in paediatrics to lead to certification in paediatrics, or an extra year which could lead to certification in general neurology.

An alternative proposal by Dr. Lemieux was that there should be five years of residency incorporating two full years of paediatrics, so that trainees could sit both the examination in paediatrics and also the examination in neurology (with special competence in child neurology) at the end of their program, as was planned in the United States. It was also suggested that the Royal College of Physicians and Surgeons might have a supervisory role with regard to the recognition of programs in different university centres.

After the inaugural meeting, the President (HGD) wrote to the Chairmen of the Royal College Committees in Neurology and in Paediatrics and also to the Secretary of the Royal College, Dr. James H. Graham, concerning training requirements. In addition, the present authors had personal discussions with some leading Canadian paediatricians and "adult" neurologists. In general, the neurologists took the view that their universitybased programmes could be modified, so that candidates would take one or two years in paediatrics instead of internal medicine, before embarking on their definitive training in neurology. It was agreed that neurologists with a major interest in paediatric neurology should form part of the examining team in both the clinical and basic science orals, but initially there was no mention of any general paediatrician among the examiners. The Council of the Royal College generally opposed separate specialist qualifications for those working in the adult field and those interested in children.

At the annual meeting in Banff in June 1972, Dr. Dunn reviewed his correspondence with Dr. D.W. Baxter, Head of the Committee on neurology at the Royal College. It was evident that the neurologists preferred a five-year training programme, like that proposed by Dr. Lemieux. Dr. Prichard and the other paediatric neurologists in Toronto supported this proposal, whereas Dr. Masotti and the group at Queen's University, Kingston, felt that the whole training should be mainly under the jurisdiction of paediatrics. The questions of including one year of training in developmental paediatrics and/or child psy- chiatry were also discussed. Further correspondence between CACN and the Royal College of Physicians and Surgeons also involved the Committee on Specialty Development and Manpower at the College, where it was evidently decided that the modification of training regulations and examinations in neurology would suffice to allow the development of paediatric neurology.

By 1974, training and examination requirements according to Royal College regulations included a paediatric neurology programme of at least four years at a recognized neurological training centre. This was to start with a minimum of one year of paediatrics, which was to be followed by at least three years of neurology-based training, as we had outlined earlier, but including at least six months of adult neurology. Trainees could opt to have an extra year of paediatric training and to sit the core examination in paediatrics prior to their study of neurology; this would exempt them from the third paper in the final examination.

The examination consisted of:

a. Three written papers: 1 . Principles and practice of neurology.

2. Clinically applied basic neuroscience (as before).

3. Paediatrics with emphasis on neurology.

b. 1. An oral examination in the clinical application of basic neuroscience conducted by a neuropathologist and clinical neurologists.

2. A clinical examination in neurology as modified for paediatric neurology with a paediatric neurologist on the Board of Examiners.

Such an examination was first held in 1975. In the Annals of the Royal College those approved university training programmes for "adult" neurologists, which were also authorized to train child neurologists (at that time McGill, Toronto and the University of British Columbia) were marked with an asterisk.

In the following year, a paediatrician was substituted for an internist as an examiner on the paediatric part of the neurology examination. The present authors were asked in turn to be examiners in paediatric neurology. At times it was necessary to 
ask for changes in the setting of questions in order to protect paediatric neurology candidates from having no alternative to discussing problems which hardly applied to their age group of patients. Also, the paediatric neurologist examiner was asked to mark only the third paper for those candidates who chose to write about neurology as applied to paediatrics and had no influence on the setting or marking of the first two papers. When these problems were pointed out to the Chairman of the English Board of Examiners, and to Dr. Firstbrook, Director, Division of Training and Evaluation at the College, they were sympathetic and some appropriate changes were made. Some discussions concerning appropriate examination procedures have continued. In the 90s, with Dr. Peter Humphreys as the paediatric neurology examiner and Dr. W.J. Becker, of Calgary, as senior "adult" neurology examiner written examinations were changed to short answer questions which are designed to plumb the candidates' knowledge and to follow the learning objectives recently developed by directors of the Canadian Programmes. ${ }^{9}$ It is now less likely that a paediatric neurology candidate will encounter questions which are only of relevance to adult neurologists.

\section{Manpower NeEdS}

From its inception, the Association recognized that staffing needs for both male and female paediatric neurologists were a major issue. The American estimate in 1970 that one paediatric neurologist was required for every 100,000 children under the age of 15 years was the basis of a report by one of us (JART) in $1976 .{ }^{10}$ Drawing on an analysis of cases referred to one paediatric neurologist in Halifax (Table 2) and also on data from Europe and the United States ${ }^{1-4}$ it was considered that the American figures might have to be modified for Canada. Thus, the requirements might be increased if the borderlands of paediatric neurology were included, such as learning disabilities, attention deficit disorder, and ongoing care of the chronically handicapped and also if the neurologist became heavily involved in academic work. Smaller numbers might be sufficient if the classic but outmoded concept persisted that a paediatric neurologist was a specialist who mostly looked at the academic puzzle of rare and incurable conditions.

More recently, in 1997, Keene and Humphreys ${ }^{11}$ have again taken stock of the manpower situation in child neurology in Canada. While CACN now has 85 members, the authors found that only about $2 / 3$ were practising child neurologists. Fortyfour $(77 \%)$ of these completed a standardized questionnaire. In

*Table 2a: Office Referrals in Pediatric Neurology (Based on 2018 Cases).

\begin{tabular}{lcc}
\hline & Number & Percent \\
\hline Epilepsy & 420 & 20.8 \\
Borderland of epilepsy & 276 & 14 \\
Learning disorders & 391 & 19.5 \\
Mental retardation & 276 & 14 \\
Psychiatry (functional) & 149 & 7.5 \\
Cerebral palsy & 138 & 7 \\
Headaches & 203 & 10 \\
All other categories & 166 & 8 \\
\hline
\end{tabular}

*Data supplied by J.A.R. Tibbles. ${ }^{10}$

\begin{tabular}{llll}
\hline $\begin{array}{l}\text { *Table 2b: Comparison of frequency in children and adults in } \\
\text { office referrals }\end{array}$ & \multicolumn{2}{c}{ Adults $(\mathrm{N}=635)$} \\
\hline \multicolumn{2}{c}{ Paediatric (N=2018) } & Headaches & $18.6 \%$ \\
Epilepsy and borderland & $34 \%$ & Epilepsy & $12.4 \%$ \\
Learning disorders & $19.5 \%$ & Functional & $11 \%$ \\
Mental retardation & $14 \%$ & Cerebrovascular & $8.4 \%$ \\
Headaches & $10 \%$ & Disc disease & $5 \%$ \\
Psychiatry (functional) & $7.5 \%$ & Degenerative & \\
Cerebral palsy & $7 \%$ & CNS disease & $5 \%$ \\
\hline
\end{tabular}

*Data supplied by J.A.R. Tibbles. ${ }^{10}$

addition, a second questionnaire was sent to Canadian University Programme Directors in child neurology. Of those physicians who completed the survey, $40 \%$ had received their degrees from a university outside Canada. Thus, this country's dependence on foreign medical graduates is clearly evident in child neurology. Sixty-three percent had been certified in neurology by the Royal College of Physicians and Surgeons of Canada; $59 \%$ had been certified in paediatrics, and $20 \%$ (20-25\% estimated) had both certifications. Sixty-five percent had full-time university or teaching hospital appointments. Keene and Humphreys also found that the ratio of paediatric neurologists for a population of 100,000 under $\underline{19}$ years of age in each province ranged from only 0.49 to 0.96 ; this compares poorly with the calculated requirement of one paediatric neurologist for every 100,000 children under the age of $\underline{15}$. Further, with the Royal College programme rising to five years, the maximum potential output would be only 1.6 paediatric neurologists per year, whereas the number needed to maintain the present inadequate status quo would be a minimum of 2.4 per year. Admittedly, the prediction of future needs is hazardous, being subject to changes in lifestyle, practice and referral patterns, advances in technology, and the "workload mix" of academic physicians. However, the present gloomy training figures are compounded by the fact that of the seven approved Canadian training programmes, only two have secure provincial government funding. For the future, ongoing manpower surveys will be needed, together with reviews of patterns of practice and other modifying factors. The national societies like $\mathrm{CACN}$ will have to supply informed advocacy to Federal and provincial health policy planners, including the funding of training programmes and of career development awards.

Even now it may safely be assumed on the basis of American experience, that there should be at least 60 practising child neurologists in Canada and to this should be added an extra number of 30 "teacher/investigators", making a total of 90 .

\section{Other CACN Activities}

As mentioned earlier, Drs. Fred and Eva Andermann repeatedly suggested that $\mathrm{CACN}$ should establish a Canadian Registry for Degenerative Diseases of Childhood and Adolescence in Montreal. They had noted certain diseases occurring with relatively high frequency in specific population groups, e.g., TaySachs disease in French Canadians from the eastern part of Quebec and a mutant juvenile form of cerebro-macular degeneration in the Lebanese communities of Montreal and Ottawa. 
Where the enzymatic defect was known, heterozygote screening and amniocentesis were to be carried out in these high-risk populations to prevent the recurrence of these disorders. To this could now be added more studies of the relevant genes and DNA. Paediatric neurologists across the country were requested to report such patients. Similar initiatives have included support for a registry of patients with sub-acute sclerosing panencephalitis, which is now maintained by Dr. Paul R. Dyken of Mobile, Alabama. Members of CACN were also asked to support an investigation of cases of Leigh's disease by Dr. G. Watters and research on the usefulness of measuring drug levels in the blood and urine of epileptic children by Drs. Peter and Carol Camfield and their collaborators. ${ }^{12,13}$ Members of CACN were particularly active in a trial of clobazam in refractory epilepsy. ${ }^{14}$ They also aided Dr. Alexander MacKenzie, Ottawa, in his studies of the molecular genetics of spinal muscular atrophy by sending him serum and fresh tissue from patients. ${ }^{15,16}$ Recently, they have been assisting Dr. Gabrielle DeVeber in her pioneering study of acute hemiplegia in children. ${ }^{17}$ Already in 1976, the Secretary, Dr. Rosalind Curtis, had asked members to notify her concerning specialized laboratory techniques performed within their centre, so that she could compile a list of these for wider use in Canada. In June 1985, the Association assisted Dr. Jean Aicardi in making a tour of Canadian academic centres as Visiting Professor. In 1995 the CACN finally became a National Specialty Society of the Royal College. In that year, the first Royal College lecture was given at the Canadian Congress of Neurological Sciences by Dr. Victor Dubowitz from London, England. Members of CACN have clearly enjoyed the annual meetings of a numerically small specialty in a large country to exchange views and develop new ideas in a friendly atmosphere.

\section{Discussion}

It will be seen that many of the older problems in integrating paediatric neurology into the wider spheres of neurophysiology, neurology and neurosurgery have been resolved. However, as pointed out by Dr. Michael Cohen, ${ }^{18}$ there are still many problems to be faced with respect to the training and manpower in child neurology. Thus, "it is counter-productive for both developmental pediatrics and child neurology to compete with one another." It remains essential as pointed out by Hagberg et al. in $1970,{ }^{4}$ that child neurologists and those who are concerned with rehabilitation of neurologically handicapped children must cooperate closely in academic centres. It is also evident that trainees in child neurology have to be familiar with the assessment of behavioural development, with habilitation of the physically and mentally handicapped, with the comprehensive care of epilepsy and with the management of learning disabilities. The academic paediatric neurologist tends to be concerned chiefly with diagnosis and acute care, research, and teaching (in addition to administration). However, he/she may also have to deal with such chronic neurologic handicaps as cerebral palsy, muscular dystrophy, the syndrome of Attention Deficit Disorder, autism, and even the mild brain dysfunctions in children of low birth weight. ${ }^{19-21}$ In all these conditions, the neurologist may have to participate in the teamwork of paediatric, social and emotional management. Accordingly training in child neurology should be diverse to meet the needs of various career plans. ${ }^{22}$

Cohen ${ }^{18}$ also suggests that prospective trainees in paediatric neuroscience should be taught in departments consisting of 10 to 20 individuals with multiple areas of interest which could extend the promise of new research technology, such as molecular biology, genetic research, biochemical investigations, gene therapy, treatment of neoplastic diseases, and new pharmacologic approaches to movement disorders and seizures. To this might be added the remarkable recent advances in neuroradiology. Out-patient clinics in paediatric neurology need to have ready access to child psychiatrists and other paediatric disciplines and require specific teams of nurses, occupational and physiotherapists, psychologists and social workers. The wider organization of neurological services to children was discussed in a booklet published by the British Paediatric Neurology Association in February 1995 under the title of "A guide for purchasers of services for children with neurological problems."

It may interest our readers that paediatric neurology was recognized as a specialty in the United Kingdom for more than 10 years until 1996 when it became a subspecialty of paediatrics, but this is being reconsidered by the Royal Colleges of Physicians. Specialty training for five and a half years is still available (without examination).

Dr. Brian G.R. Neville, Professor of Paediatric Neurology at the Institute of Child Health in London, has recently summarized the situation in European countries. ${ }^{23} \mathrm{He}$ finds that paediatric neurology is recognized as a specialty in Belgium, Estonia, Finland, Hungary, Ireland, the Netherlands, Poland and Sweden. However, there is a wide variation with respect to training programs, examinations, specialty positions (academic and regional), and relationship to other specialties.

\section{SUMMARY}

During its history of more than 25 years, the Canadian Association for Child Neurology has grown and has participated in increasing academic activity. Some problems remain, particularly with respect to manpower requirements and the relationship to experts in developmental paediatrics and in the rehabilitation of children with chronic neurological handicaps. Training centres should provide clinical and research experience in a broad range of neurosciences and in genetics, but also in developmental paediatrics, social studies, child psychiatry, and neuro-psychology.

\section{ACKNOWLEDGEMENTS}

The authors wish to thank Drs. John Crichton, Alan Hill, Daniel Keene and Peter Humphreys for helpful comments.

\section{REFERENCES}

1. NINDS Training Program; National Manpower Needs, July 1970

2. Carter $S$. Of priorities, promise and the path ahead. Neurology 1971; 21: 877-888.

3. Severinghaus, AE. Neurology: a medical discipline takes stock. DHEW Publication No. (NIH) 72-175. Washington DC: Govt. Printing Office 1971: 74-80.

4. Hagberg B, Ingram TTS, MacKeith R. Development of paediatric neurology. Lancet 1970; 11: 940-942.

5. Robb, P. Personal reminiscences: the development of neurology at the Montreal Children's Hospital. Pediatr Neurol 1996; 14: 185188.

6. Shevell MI. Gordon V. Watters, MD. A brief biography. Pediatr Neurol 1996; 14: 182-184. 
7. Swaiman KF. The organization of the Child Neurology Society: a personal view. Pediatr Neurol 1996; 15: 9-16.

8. Blaw ME, Rapin I, Kinsbourne M, eds. Topics in Child Neurology. Jamaica, NY; Spectrum Publications, 1977.

9. Becker WJ. Clinical problem-based objectives for specialty training in adult neurology. Annals RCPSC 1995; 28: 161-164.

10. Tibbles JAR. The functions and the training of a paediatric neurologist. Develop Med Child Neurol 1976; 18: 167-172.

11. Keene DL, Humphreys P. Pediatric neurology manpower requirements. Annals RCPSC 1997; 30: 165-168.

12. Camfield P, Camfield C. Dooley J, et al. Routine screening of blood and urine for severe reactions to anticonvulsant drugs in asymptomatic patients is of doubtful value. Can Med Assoc $J$ 1989; 140: 1303-1305.

13. Dooley JM, Camfield PR, Camfield CS, Gordon K, Fraser AM. The use of antiepileptic drug levels in children. A survey of Canadian Pediatric Neurologists. Can J Neurol Sci 1993; 20: 217-221.

14. Canadian Clobazam Cooperative Group. Clobazam in treatment of refractory epilepsy: the Canadian experience. A retrospective study. Epilepsia 1991; 32: 407-416.

15. MacKenzie A, Roy N, Besner A, et al. Genetic linkage analysis of Canadian spinal muscular atrophy kindreds using flanking microsatellite 5q13 polymorphisms. Hum Genet 1993; 90 501504.
16. Roy N, Mahadevan MS, McLean M, et al. The gene for neuronal apoptosis inhibiting protein is partially deleted in individuals with spinal muscular atrophy. Cell 1995; 80: 167-178.

17. DeVeber GA. Canadian Pediatric Ischemic Stroke Registry: an updated analysis. Can J Neurol Sci 1995; 22 (Suppl. 1): S24.

18. Cohen ME. Child neurology: restructuring for survival in the future. J Child Neurol 1992; 7: 3-6.

19. Dunn HG, ed. Sequelae of low birthweight: the Vancouver Study. Clinics in Developmental Medicine 1986; No.95/96. MacKeith Press, Oxford:Blackwell; Philadelphia:Lippincott; 1-306.

20. Paneth JN, Rudelli R, Kazam E, Monte W. Brain damage in the preterm infant. Clinics in Developmental Medicine 1993; No.131. MacKeith Press, New York: Cambridge University Press; 1-223.

21. Klebanov PK, Brooks-Gunn J, McCormick MC. Classroom behaviour of very low birth weight elementary school children. Pediatrics 1994; 94: 700-708.

22. Fishman MA. Child neurology: past, present and future. J Child Neurol 1996; 11: 331-335.

23. Neville, BGR. Results of European paediatric neurology survey of status and training programmes (personal communication). 